\title{
Performance of micro-nutrients on growth and yield attributes of linseed (Linum usitatissimum L.) under limited irrigation
}

\author{
Adarsh Verma, Amar Kant Verma*, U.D. Awasthi, Avadh Narain Singh ${ }^{1}$ and Kushal Sachan \\ Department of Soil Conservation and Water Management/SSAC, C.S. Azad University of Agriculture and \\ Technology, Kanpur (U.P.) India (Email: amarkant9004@gmail.com)
}

\begin{abstract}
A field experiment was conducted during Rabi season of 2019-20 at Oil Seed Research Farm of C S Azad University of Agriculture and Technology, Kanpur. The experiment consisted 9 treatments viz. $\mathrm{T}_{1}$ : Control, $\mathrm{T}_{2}$ : Soil application of $\mathrm{ZnSO}_{4} @ 25$ $\mathrm{kg} \mathrm{ha}^{-1}, \mathrm{~T}_{3}$ : Foliar application of $\mathrm{ZnSO}_{4} @ 0.5 \%$ at $45 \mathrm{DAS}, \mathrm{T}_{4}$ : Soil Application of $\mathrm{ZnSO}_{4} @ 25 \mathrm{~kg} \mathrm{ha}^{-1}+$ Foliar application of ZnSO @0.5\% at 45 DAS, $\mathrm{T}_{5}$ : Soil application Borax @ $1.5 \mathrm{~kg} \mathrm{ha}^{-1}, \mathrm{~T}_{6}$ : Foliar application of Borax @ $0.3 \%$ at 45 DAS, $\mathrm{T}_{7}$ : Soil application of Borax@1.5 kg ha-1 Foliar application of Borax @ $0.3 \%$ at 45 DAS, T : Foliar application of ZnSO $@ 0.5 \%+$ Borax @ $0.3 \%$ at $45 \mathrm{DAS}$ and $\mathrm{T}_{9}$ : Soil application of $\mathrm{ZnSO}_{4} @ 25 \mathrm{~kg} \mathrm{ha}^{-1}+$ Borax @ $1.5 \mathrm{~kg} \mathrm{ha}^{-1}$ in soil assigned in Randomized Block Design with three replication. The Linseed cv Shekhar was used in the experiment. The results in significantly maximum plant stand, plant height, yield attributes: Days to $50 \%$ flowering and maturity, Number of capsules plant ${ }^{-1}$ and number of seeds capsule ${ }^{-1}, 1000$-seed weight $(\mathrm{g})$ was significantly affected by $\mathrm{T}_{9}$ and $\mathrm{T}_{8}$ treatments. The highest 1000 -seed weight $(8.97)$ under $\left(\mathrm{T}_{9}\right)$ treatment were soil application of $\mathrm{ZnSO}_{4} @ 25 \mathrm{~kg} \mathrm{ha}^{-1}+$ Borax @ $1.5 \mathrm{~kg} \mathrm{ha}^{-1}$ at the time of sowing as compared to all the treatments except treatment No. $\left(\mathrm{T}_{8}\right)$ Foliar application of $\mathrm{ZnSO}_{4} @ 0.5 \%$ + Borax @ $0.3 \%$ at 45 DAS under limited irrigation of central Uttar Pradesh.
\end{abstract}

Key Words : Plant stand, Plant height, 1000-seed weight, Micro-nutrient

View Point Article : Verma, Adarsh, Verma, Amar Kant, Awasthi, U. D., Singh, Avadh Narain and Sachan, Kushal (2021). Performance of micro-nutrients on growth and yield attributes of linseed (Linum usitatissimum L.) under limited irrigation. Internat. J. agric. Sci., 17 (AAEBSSD) : 287-291, DOI:10.15740/HAS/IJAS/17-AAEBSSD/287-291. Copyright@2021: Hind Agri-Horticultural Society.

Article History : Received : 01.08.2021; Accepted : 03.08.2021

\section{INTRODUCTION}

Linseed [Linum usitatissimum (L.)] is highly nutritious, unique and emerging among oilseeds for its technical grade vegetable oil and good quality fibre producing ability. Globally, among the oilseeds linseed or flax is one of the oldest oilseed crops grown widely in Asia, America and Europe for oil, fibre and seed purpose. India has fourth largest vegetable oil economy in the world after USA, China and Brazil. Oilseeds are the second largest agricultural commodity after cereals sharing 14 $\%$ of gross cropped area, $6 \%$ of gross national product and $10 \%$ of the agriculture product value in the country. The demand, supply and gap of edible oil in India are $18.94,10.08$ and 8.86 (47\%) million tons, respectively (Anonymous, 2020).

The demand for edible oils is continuously increasing due to ever increasing population and improvement in the standard of living. In India, linseed is a major winter

\footnotetext{
*Author for correspondence:

${ }^{1}$ Department of Agronomy, Acharya Narendra Deva University of Agriculture and Technology, Kumarganj, Ayodhya (U.P.) India
} 
(Rabi) season oilseed crop next to rapeseedmustard. It is a good source of complete protein, high order linolenic acid, carbohydrates, vitamins, minerals and grown for dual purpose-seed and fibre (Sharma et al., 2017). Linseed oils are used as vegetable oil and especially important for industrial uses. So, great emphasis has to be placed on increasing its production to meet the requirements. On the other hand, excessive use and continuous increase in cost of irrigation inspired us to explore the possibilities to restrict the water loss. It is true that farmers are far behind the expectations of irrigation adoption in a scientific manner. They need comprehensive technological support which is simple to use and easy to integrate into farm management. In future, due to climate change and shrinking water availability, demand for irrigation might not meet fully. Adequate and timely water application is a basic prerequisite for proper plant growth for augmenting crop yield. Limited quantity of water available for irrigation calls for scheduling of irrigation which can avoid excess water applied to the crop and thereby water productivity of linseed could also be improved. Therefore, irrigation is being scheduled based on climatological approach which is considered as most scientific, since it integrate all weather parameters giving them natural weightage in a given.

Climate-plant continuum (Parihar et al., 1976). To reduce evaporation loss of water and enhance moisture availability to crop the most appropriate agronomical moisture conservation practice is mulching. Organic mulches are poor conductor of heat that effectively reduce soil temperature and retain soil moisture for longer period (Vaidya et al., 1995). Biodegradable mulching materials are not able to compete with polythene mulch due to uncontrolled degradation behavior, poor mechanical properties and high cost. Non degradable polythene mulch enhances crop water use efficiency, water productivity but cause pollution if not disposed of from the field after harvesting of the crop. The present experiment was therefore, undertaken with aimed to find out efficient irrigation schedules with optimum requirement and suitable moisture conservation practices for enhancing production and productivity of linseed.

\section{Material AND Methods}

The experiment was conducted during Rabi season of 2019-20 in Oil Seed Research Farm of C.S. Azad University of Agriculture and Technology, Kanpur in alluvial soil. Soil of the experimental plot was sandy loam in texture and slightly calcareous having organic carbon $0.33 \%$, total nitrogen $0.034 \%$, available $\mathrm{P}_{2} \mathrm{O}_{5} 16.8 \mathrm{Kg}$ $\mathrm{ha}^{-1}$, available $\mathrm{K}_{2} \mathrm{O} 156.4 \mathrm{~kg} \mathrm{ha}^{-1}, \mathrm{pH} 7.7$, electrical conductivity $0.38 \mathrm{dS} \mathrm{m}^{-1}$, permanent wilting point $6.3 \%$, field capacity $18.2 \%$, maximum water holding capacity $29.7 \%$, bulk density $1.45 \mathrm{Mg} \mathrm{m}^{-3}$, particle density 2.57 $\mathrm{Mg} \mathrm{m}^{-3}$ and porosity $43.57 \%$. The experiment consisted 9 treatments viz. $\mathrm{T}_{1}$ : Control, $\mathrm{T}_{2}$ : Soil application of $\mathrm{ZnSO}_{4} @ 25 \mathrm{~kg} \mathrm{ha}^{-1}, \mathrm{~T}_{3}$ : Foliar application of $\mathrm{ZnSO}_{4}$ @ $0.5 \%$ at $45 \mathrm{DAS}, \mathrm{T}_{4}$ : Soil Application of $\mathrm{ZnSO}_{4} @ 25$ $\mathrm{kg} \mathrm{ha}^{-1}+$ Foliar application of $\mathrm{ZnSO}_{4} @ 0.5 \%$ at $45 \mathrm{DAS}$, $\mathrm{T}_{5}$ : Soil application Borax @ $1.5 \mathrm{~kg} \mathrm{ha}^{-1}, \mathrm{~T}_{6}$ : Foliar application of Borax@0.3\% at 45 DAS, T application of Borax@1.5 kg ha-1 Foliar application of Borax@0.3\% at 45 DAS, T. Foliar application of $\mathrm{ZnSO}_{4} @ 0.5 \%+$ Borax@0.3\% at 45 DAS and $\mathrm{T}_{9}$ : Soil application of $\mathrm{ZnSO}_{4} @ 25 \mathrm{~kg} \mathrm{ha}^{-1}+$ Borax @ 1.5 $\mathrm{kg} \mathrm{ha}^{-1}$ in soil assigned in Randomized Block Design with three replication. The Linseed cv Shekhar was used in the experiment. A uniform dose of $30 \mathrm{~kg} \mathrm{~N}+15 \mathrm{~kg} \mathrm{P} \mathrm{O}_{5}$ $+15 \mathrm{~kg} \mathrm{~K}_{2} \mathrm{O} \mathrm{ha}^{-1}$ was applied as basal at sowing through funnel attached with country plough used for seed sowing. The fertilizer used were urea DAP, Borex, Zinc and muriate of potash. Available moisture at sowing time upto $100 \mathrm{~cm}$ soil profile was $307.23 \mathrm{~mm}$. Whereas amount of rainfall received during the crop period was $61.8 \mathrm{~mm}$ against the average annual rainfall of about $800 \mathrm{~mm}$. Recommended package of practices were applied in different treatments. Soil moisture was monitored gravimetrically using the sample collected from $0-25,25-$ $50,50-75$ and $75-100 \mathrm{~cm}$ soil depths at regular monthly intervals to quantify the soil moisture content and growth parameters by randomly selecting three plants for each plots till the harvest.

The data collected on growth and yield attributes were statistically analyzed (Fisher and Yates, 1958). Recommended package of practices and fertilizers doses were applied in different treatments.

\section{RESUlTS AND DisCuSSION}

The results obtained from the present investigation as well as relevant discussion have been summarized under following heads :

\section{Initial and final plant stand $\left(000 \mathrm{ha}^{-1}\right)$ :}

Plant stand $\left(000 \mathrm{ha}^{-1}\right)$ of linseed did not influenced significantly by different treatments of micronutrient 
application. Similar results have also been observed by Sarkar and Sarkar, (2017).

\section{Plant height $(\mathrm{cm})$ :}

The plant height $(\mathrm{cm})$ was recorded at 30 days after sowing which has been presented in (Table 1). The plant height was significantly influenced by different treatments. Soil application of $\mathrm{ZnSo}_{4} @ 25 \mathrm{~kg} \mathrm{ha}^{-1}+$ Borax @ $1.5 \mathrm{~kg} \mathrm{ha}^{-1}$ at the time of sowing resulted in significantly higher. It is evident from data that plant height $(\mathrm{cm})$ was significantly affected by various treatments. The highest plant height $(26.50 \mathrm{~cm})$ under $\mathrm{T}_{9}$ (Soil application of $\mathrm{ZnSO}_{4} @ 25 \mathrm{~kg} \mathrm{ha}^{-1}+$ Borax @ $1.5 \mathrm{~kg} \mathrm{ha}^{-1}$ ) as compared to all the treatments and lowest plant height $(19.67 \mathrm{~cm})$ was recorded under $T_{1}$ (Control). The plant height $(\mathrm{cm})$ was recorded at 60 days after sowing plant height $(\mathrm{cm})$ was significantly affected by various treatments. The highest plant height $(44.63 \mathrm{~cm})$ was recorded under $\mathrm{T}_{9}$ (Soil application of $\mathrm{ZnSO}_{4} @ 25 \mathrm{~kg} \mathrm{ha}^{-1}+$ Borax @ 1.5 $\mathrm{kg} \mathrm{ha}^{-1}$ ) followed by treatment and lowest plant height $(39.78 \mathrm{~cm})$ under treatment $\mathrm{T}_{1}(\mathrm{Control})$. The plant height (cm) was recorded at 90 days after sowing plant height

\begin{tabular}{|c|c|c|c|c|c|c|c|c|c|c|}
\hline \multirow[t]{2}{*}{ Treatments } & \multicolumn{2}{|c|}{ Plant stand $\left(000 \mathrm{ha}^{-1}\right)$} & \multicolumn{4}{|c|}{ Plant height $(\mathrm{cm})$} & \multicolumn{4}{|c|}{ Dry matter accumulation $\left(\mathrm{g}\right.$ plant $\left.^{-1}\right)$} \\
\hline & Initial & Final & 30 DAS & $60 \mathrm{DAS}$ & 90 DAS & At harvest & 30 DAS & 60 DAS & 90 DAS & At harvest \\
\hline $\mathrm{T}_{1}$ & 590.67 & 589.86 & 19.67 & 39.78 & 42.05 & 44.20 & 8.13 & 9.21 & 10.11 & 9.21 \\
\hline $\mathrm{T}_{2}$ & 605.81 & 603.69 & 23.63 & 41.31 & 46.02 & 46.58 & 8.26 & 10.11 & 10.18 & 10.19 \\
\hline $\mathrm{T}_{3}$ & 603.16 & 602.05 & 22.00 & 43.76 & 44.74 & 45.81 & 8.46 & 10.37 & 11.39 & 10.34 \\
\hline $\mathrm{T}_{4}$ & 608.70 & 606.75 & 23.66 & 40.28 & 45.53 & 45.78 & 9.00 & 11.12 & 11.65 & 11.06 \\
\hline $\mathrm{T}_{5}$ & 607.90 & 604.53 & 22.00 & 43.76 & 44.74 & 45.81 & 8.81 & 10.57 & 11.40 & 10.40 \\
\hline $\mathrm{T}_{6}$ & 607.00 & 605.88 & 22.09 & 43.98 & 45.00 & 45.08 & 9.11 & 11.34 & 11.78 & 11.24 \\
\hline $\mathrm{T}_{7}$ & 609.42 & 608.09 & 24.04 & 41.67 & 45.23 & 46.04 & 9.32 & 11.64 & 12.00 & 11.58 \\
\hline $\mathrm{T}_{8}$ & 611.76 & 610.34 & 26.00 & 44.04 & 47.44 & 48.56 & 9.56 & 11.73 & 12.25 & 11.72 \\
\hline $\mathrm{T}_{9}$ & 612.65 & 611.42 & 26.50 & 44.63 & 48.58 & 49.18 & 9.93 & 11.90 & 12.46 & 11.93 \\
\hline S.D. \pm & 0.57 & 0.59 & 0.38 & 0.31 & 0.58 & 0.49 & 0.75 & 0.84 & 0.85 & 0.94 \\
\hline C.D. $(\mathrm{P}=0.05)$ & N.S. & N.S. & 0.83 & 0.68 & 1.27 & 1.07 & 1.59 & 1.69 & 1.71 & 1.99 \\
\hline
\end{tabular}

$\mathrm{T}_{1}$ : Control, $\mathrm{T}_{2}$ : Soil application of $\mathrm{ZnSO}_{4} @ 25 \mathrm{~kg} \mathrm{ha}^{-1}, \mathrm{~T}_{3}$ : Foliar application of $\mathrm{ZnSO}_{4} @ 0.5 \%$ at $45 \mathrm{DAS}, \mathrm{T}_{4}$ : Soil Application of $\mathrm{ZnSO}_{4}$

@ $25 \mathrm{~kg} \mathrm{ha}^{-1}$ + Foliar application of $\mathrm{ZnSO}_{4} @ 0.5 \%$ at $45 \mathrm{DAS}, \mathrm{T}_{5}$ : Soil application Borax@ $1.5 \mathrm{~kg} \mathrm{ha}^{-1}, \mathrm{~T}_{6}$ : Foliar application of Borax @ $0.3 \%$ at $45 \mathrm{DAS}$, $\mathrm{T}_{7}$ : Soil application of Borax@1.5 kg ha ${ }^{-1}$ Foliar application of Borax @ $0.3 \%$ at 45 DAS, $\mathrm{T}_{8}$ : Foliar application of $\mathrm{ZnSO}_{4} @ 0.5 \%+\mathrm{Borax}_{0} @ 0.3 \%$ at 45 DAS and T: Soil application of $\mathrm{ZnSO}_{4} @ 25 \mathrm{~kg} \mathrm{ha}^{-1}+$ Borax @ $1.5 \mathrm{~kg} \mathrm{ha}^{-1}$

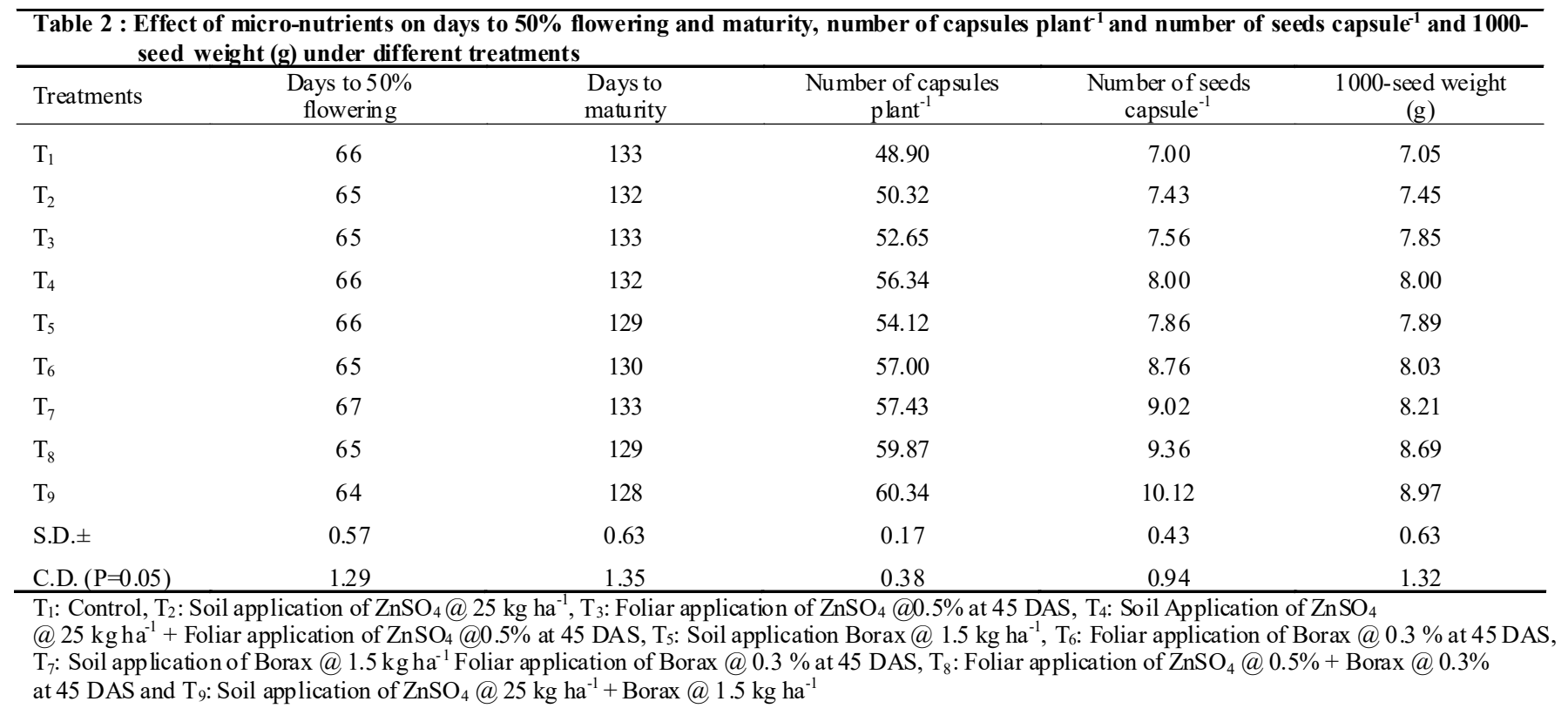


(cm) was significantly affected by various treatments. The highest plant height $(48.58 \mathrm{~cm})$ under $\mathrm{T}_{9}$ (Soil application of $\mathrm{ZnSO}_{4} @ 25 \mathrm{~kg} \mathrm{ha}^{-1}+$ Borax @ $\left.1.5 \mathrm{~kg} \mathrm{ha}^{-1}\right)$ as compared to all the treatments and lowest plant height $(42.05 \mathrm{~cm})$ under $\mathrm{T}_{1}(\mathrm{Control})$. The plant height $(\mathrm{cm})$ was recorded at harvesting plant height $(\mathrm{cm})$ was significantly affected by various treatments. The highest plant height $(49.18 \mathrm{~cm})$ under $\mathrm{T}_{9}$ (Soil application of $\mathrm{ZnSO}_{4} @ 25 \mathrm{~kg} \mathrm{ha}^{-1}+$ Borax@1.5 kg ha-1) as compared to all the treatments and lowest plant height $(44.20 \mathrm{~cm})$ under $T_{1}$ (Control). These findings are in line with those of Verma and Yadav (2017) and Omidbaigi et al. (2019).

\section{Dry matter accumulation (g plant $\left.{ }^{-1}\right)$ :}

The dry matter accumulation $\left(\mathrm{g} \mathrm{plant}^{-1}\right)$ at 30,60 , 90 and at harvest stage. It is evident from data that dry matter accumulation $\left(\mathrm{g}\right.$ plant $\left.{ }^{-1}\right)$ was significantly affected by various treatments No. $\mathrm{T}_{4}, \mathrm{~T}_{6}, \mathrm{~T}_{7}, \mathrm{~T}_{8}$, and $\mathrm{T}_{9}$. The highest dry matter accumulation under $\mathrm{T}_{9}$ (Soil application of $\mathrm{ZnSO}_{4} @ 25 \mathrm{~kg} \mathrm{ha}^{-1}+$ Borax @ $\left.1.5 \mathrm{~kg} \mathrm{ha}^{-1}\right)$. Similar results were reported by Lodhi et al. (2007).

\section{Days to 50\% flowering and maturity :}

Days to $50 \%$ flowering and maturity all the treatments having micronutrient application resulted best treatment of soil application of $\mathrm{ZnSO}_{4} @ 25 \mathrm{~kg} \mathrm{ha}^{-1}+$ Borax@1.5 kg ha-1 were identified for days to $50 \%$ flowering and days to maturity is earlier than other treatments. Similar results were reported by Gabiana et al. (2005).

\section{Number of capsules plant ${ }^{-1}$ and number of seeds capsule $^{-1}$ :}

Number of capsule plant ${ }^{-1}$ as presented in (Table 2 ). It is evident from data that number of capsule plant ${ }^{-}$ ${ }^{1}$ was significantly affected by various treatments. The highest number of capsule plant ${ }^{-1}(60.34)$ under $T_{9}$. In all treatments was recorded significantly as compared to treatment under $\mathrm{T}_{1}$ (Control) (48.90). It is evident from data that number of seeds capsule ${ }^{-1}$ was significantly affected by various treatments No. $\mathrm{T}_{4}, \mathrm{~T}_{6}, \mathrm{~T}_{7}, \mathrm{~T}_{8}$ and $\mathrm{T}_{9}$. The highest number of seeds capsule ${ }^{-1}(10.12)$ under $T_{9}$ (Soil application of $\mathrm{ZnSO}_{4} @ 25 \mathrm{~kg} \mathrm{ha}^{-1}+$ Borax @ 1.5 $\mathrm{kg} \mathrm{ha}^{-1}$ ) and lowest (7.00) under $\mathrm{T}_{1}$ (Control). Similar observations have also been reported by Verma and Yadav(2017).

\section{0-seed weight (g):}

The 1000-seed weight (g) was recorded and presented in (Table 2). It is evident from data that 1000seed weight $(\mathrm{g})$ was significantly affected by $\mathrm{T}_{9}$ and $\mathrm{T}_{8}$ treatments. The highest 1000 -seed weight $(8.97 \mathrm{~g})$ in treatment $\left(\mathrm{T}_{9}\right)$ (Soil application of $\mathrm{ZnSO}_{4} @ 25 \mathrm{~kg} \mathrm{ha}^{-1}+$ Borax@1.5 kg ha-1) as compared to all the treatments except treatment No. $\mathrm{T}_{8}$ and lowest under control $\left(\mathrm{T}_{1}\right)$ $(7.05 \mathrm{~g})$. Similar results were reported by Verma and Yadav (2018).

\section{Conclusion:}

On the basis of results obtained it can be concluded that application of $\mathrm{ZnSO}_{4} @ 25 \mathrm{kgha}^{-1}+$ Borax @ 1.5 $\mathrm{kg} \mathrm{ha}^{-1}$ incorporated in the soil and 50\% flowering and days to maturity is earlier than other treatments have fetched highest plant height and number of capsules plant $^{-1}$ quite remunerative for higher productivity along with 1000-seed weight in light textured alluvial soil of Uttar Pradesh.

\section{REFERENCES}

Anonymous (2020). Ministry of Statistics and Programme Implementation. Agricultural statistics, India.

Fisher, R.A. and Yates, Y.E. (1958). Report on coordination of fishers statistics in India. A Handbook of Agricultural statistics, 17: 47.

Gabiana, C., McKenzie, B.A. and Hill, G.D. (2005). The influence of plant population, nitrogen and irrigation on yield and yield components of linseed. Agronomy New Zealand, 35: 44-56.

Lodhi, M.D., Singh, U.P., Chauhan, D.V.S. and Verma, N.K. (2007). Studies on the effect of different dates of sowing varieties and number of irrigations on growth, yield and quality of linseed (Linumu sitatissimum L.). Bhartiya Krishi Anusandhan Patrika, 22(4): 295-298.

Omidbaigi, R., Tabatabaei, S.M.F. and Akbari, T. (2019). Effects of $\mathrm{N}$-fertilizers and irrigation on the productivity (growth, seed yield, and active substances) of linseed. Iranian Journal of Agricultural Sciences, 32(1): 53-64.

Parihar, S.S., Khera, K.L., Sandhu, K.S. and Sandhu, B.S. (1976). Comparison of irrigation schedule based on pan evaporation and growth stages in wheat. Agronomy Journal, 68: 650-653.

Sarkar, S. and Sarkar, A. (2017). Impact of irrigation schedules and mulch on productivity and moisture extraction pattern of linseed (Linum usitatissimum L.). Journal of Oilseeds Research, 34 (4): 207-211. 
Performance of micro-nutrients on growth \& yield attributes of linseed under limited irrigation

Sharma, D., Satish, P. and Ranjana, P. (2017). Study on genetic divergence analysis of indigenous and exotic lines of linseed (Linum usitatissimum L.) based on morphological and quality traits. Journal of Oilseeds Research, 34(1): 38-43.

Vaidya, V.B., Varshneya, M.C., Bote, N.L. and Naidu, T.R.V. (1995). Estimation of thermal efficiency and apparent reflectivity of mulches using soil temperature. Journal of Maharashtra Agricultural Universities, 20(3): 341-344.

Verma, Amar Kant and Yadav, P.N. (2017). Effect of linseed based intercropping systems and integrated nutrient management on growth, yield and harvest index under rainfed condition. Progressive Research, 12 (4): 458-462.

Verma, Amar Kant and Yadav, P.N. (2017). Influence of linseed (Linum usitatissimum L.) based cropping systems and integrated nutrient management on productivity potential under rainfed condition. Progressive Research, 12 (SpecialIII): 2060-2064.

Verma, Amar Kant and Yadav, P.N. (2018). Productivity and water-use efficiency of linseed (Linum usitatissimum L.) based cropping systems as influenced by integrated nutrient management under rainfed condition. Journal of Soil and Water Conservation, 17 (1): 53-57.

$16^{\text {thear }}$

$\star \star \star \star \star$ of Excellence $\star \star \star \star \star$ 